\title{
Study on the Economical Production Scale at Chiba Works*
}

\section{By Ichirō Fujimoto**}

\section{Introduction}

In February 1951, Kawasaki Steel Corporation commenced the construction of the first integrated plant after World War II on a 3,300,000 $\mathrm{m}^{2}$ reclaimed land located on the southern seashore of Chiba City.

Initially, a 1,000,000-ton scale plant was intended but afterwards actual production has been raised steadily to the present annual rate of about 4,000,000 tons of ingots, due to the progress in steelmaking techniques. Study on the most suitable production scale for the total of about $4,000,000 \mathrm{~m}^{2}$ land, including additional $660,000 \mathrm{~m}^{2}$ of reclaimed land in the neighbouring Oihama district, led to the conclusion that production of 5,000,000 tons of ingots is most reasonable, considering the most economical operation of present steelmaking equipment.

Moreover, iron-making and rolling equipment connecting with steel shops, have been found to be roughly balanced with this production level, so that this is regarded as the final production level at Chiba Works. Fig. 1 shows the general view of Chiba Works at its completion. The purpose of this lecture is to explain the details which enabled us to determine the economical production level, and the plan of Chiba Works when it is completed as an annual 5,000,000-ton production scale plant.

\section{Steelmaking Equipment}

In calculating the economical production scale, it is reasonable to study at first the capacity of the melting shop which is the basic equipment in the plant, and then that of the accessory equipment such as ironmaking and rolling.

Steelmaking equipment consists of open hearth and LD converter shops. The open hearth shop has six furnaces each with 150 ton nominal capacity, and the converter shop houses two LD converters of 150 ton nominal capacity, the third one to be installed in July 1965. With its installation there can be introduced the system of operation in which two converters are blowing while the third one is being relined. Table 1 shows the outline of steelmaking equipment.

\section{Steelmaking Capacity of $\mathrm{O}-\mathrm{H}$ Shop}

Various inquiries into the utilization of a large quantity of oxygen in $\mathrm{O}-\mathrm{H}$ shop of this plant have demonstrated that for promoting furnace productivity it was more effective to blow oxygen into the metal bath rather than to use it for accelerating combustion.
Table 1. Outline of steelmaking equipment

\begin{tabular}{|c|c|c|c|c|c|}
\hline Shop & $\begin{array}{l}\text { Furnace } \\
\text { No. }\end{array}$ & $\begin{array}{c}\text { Normal } \\
\text { capacity } \\
\text { (t/heat) }\end{array}$ & Furnace type & $\begin{array}{l}\text { Date } \\
\text { of con- } \\
\text { structions }\end{array}$ & Remarks \\
\hline \multirow{6}{*}{$\mathrm{O}-\mathrm{H}$} & No. 1 & 150 & Basic, stational & Jan. 1954 & $\begin{array}{l}\text { Remodeled } \\
\text { Jun. } 1959\end{array}$ \\
\hline & No. 2 & ," & ," & Mar. 1954 & Nov. 1959 \\
\hline & No. 3 & ," & Maerz-Boelens & Jun. 1954 & Jan. 1960 \\
\hline & No. 4 & ," & Basic, stational & Nov. 1959 & \\
\hline & No. 5 & ," & ," & Dec. 1959 & \\
\hline & No. 6 & ," & ," & Apr. 1960 & \\
\hline \multirow{3}{*}{ LD } & No. 1 & 150 & $\begin{array}{l}\text { Concentric, bot- } \\
\text { tom unremovable }\end{array}$ & Apr. 1962 & $\begin{array}{l}\text { Inner volume: } \\
242.4 \mathrm{~m}^{3}\end{array}$ \\
\hline & No. 2 & ," & ," & Jun. 1962 & , \\
\hline & No. 3 & ," & ," & Jul, 1965 & ," \\
\hline
\end{tabular}

This shop has actually attained an annual production of 2,000,000 tons of ingots with an oxygen plant capable of generating $13,400 \mathrm{Nm}^{3} / \mathrm{hr}$.

However, as a result of the development of the oxygen converter process in recent years, it has become clear that the LD converter is superior to the $\mathrm{O}-\mathrm{H}$ furnace in operation cost even when the latter is operated most efficiently, and the O-H furnaces had to be operated most economically to keep pace with the LD converters. Then the steelmaking capacity of the O-H shop when it was operated with the lowest cost was calculated on the basis of the actual results of economical operation conducted in 1962 in order to cope with the recession at that time.

In the calculation of the various factors determining the production cost of ingot, the main factors varying with production tonnages were summed up and the results were compared with various production levels. For this purpose, a study on several relations described below was conducted. Data adopted here were obtained on the basis of the premises that hot metal rate was $70 \sim 75 \%$ and amount of good ingots was 158 tons per heat with operation of five furnaces at all times.

Relation between Amount of Oxygen Consumed and Number of Heat

As shown in Fig.2, there exists a close correlation between them, and the amount of heat is in proportion

* This is the Hattori Prize lecture which was delivered before the Special Lecture Meeting of the Institute's Prize Winners held on April 4, 1964 at University of Tokyo.

** Executive Vice-President and Director, Kawasaki Steel Corporation. 


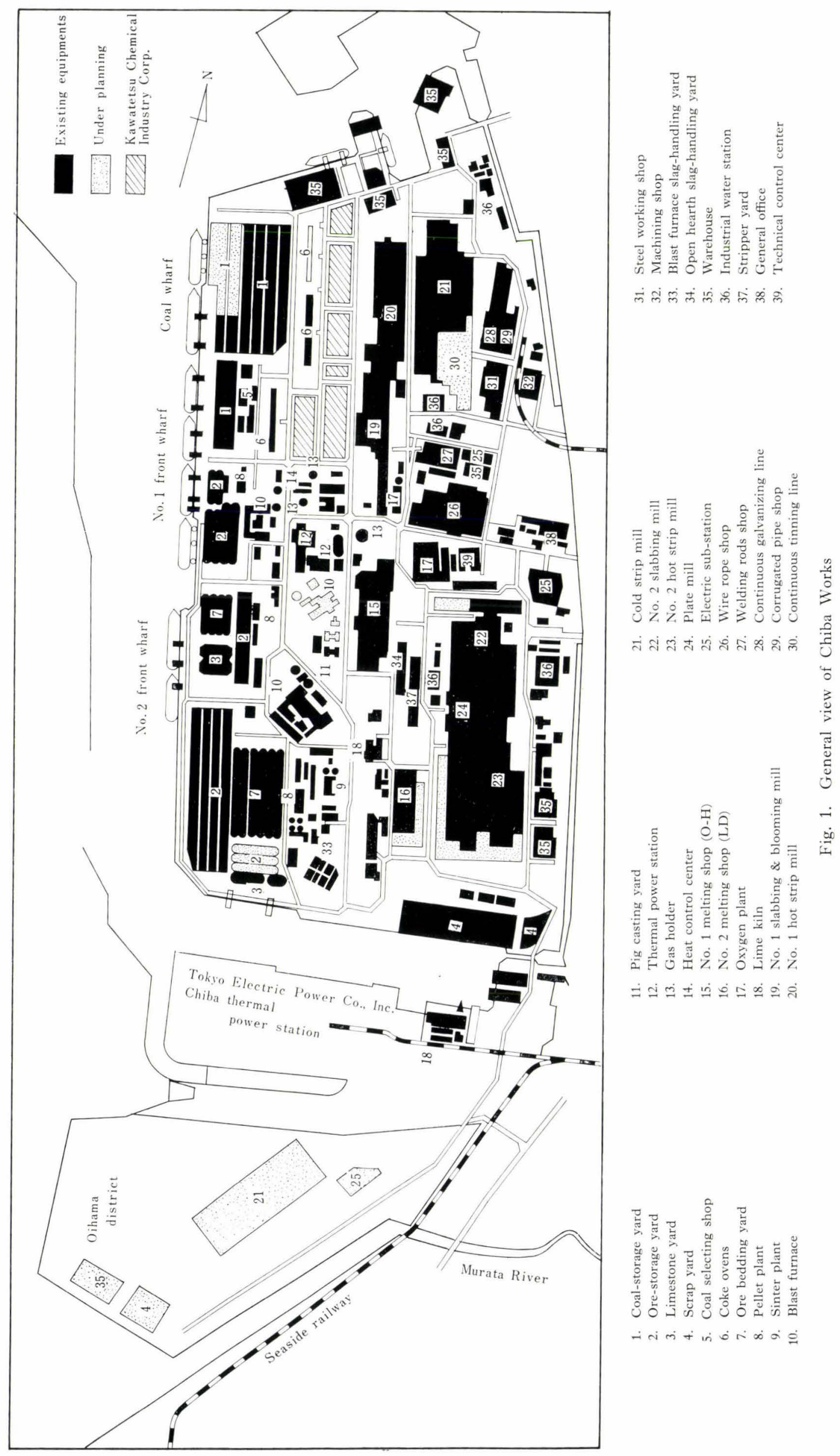


to the amount of oxygen. From this relation oxygen consumption per ton of ingot for a certain tonnage of production can be calculated.

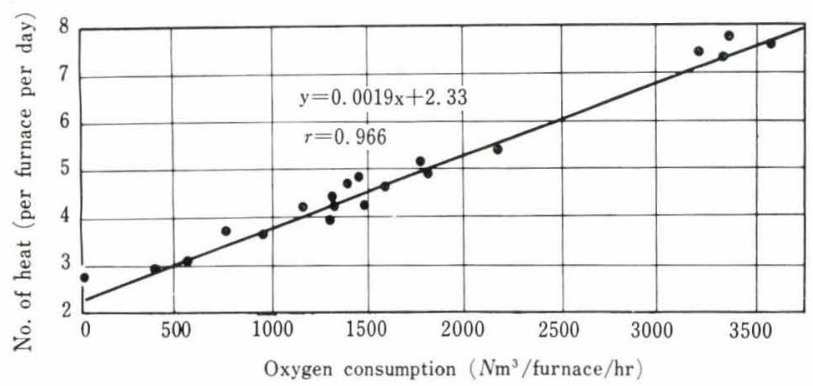

Fig. 2. Relation between oxygen consumption and number of heat

Relation between Amount of Oxygen Consumed and Steelmaking Yield

Fig.3 shows that as the amount of oxygen increases, steelmaking yield decreases. This is because the increase in the amount of oxygen brings the increase in the volumes of flash-slag and metal, while decreasing tonnage of iron ore used.

From the two relations shown above, steelmaking yield and, accordingly, cost of metallic charges for each production level can be calculated.

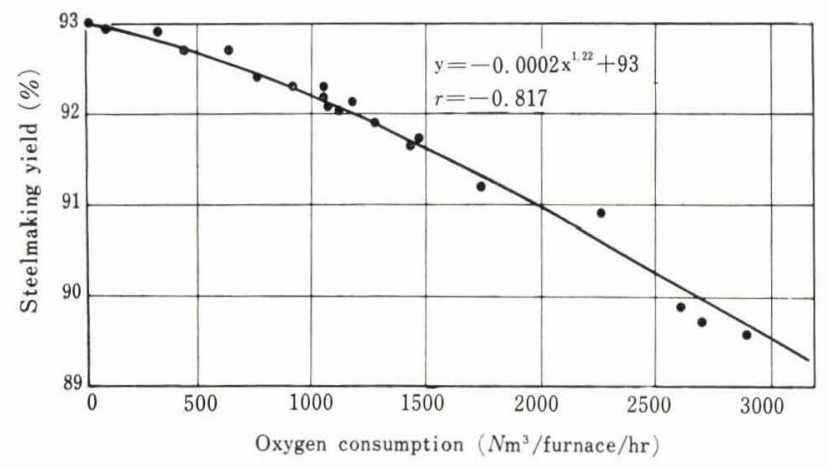

Fig. 3. Relation between oxygen consumption and steelmaking yield

Relation between Fuel Consumption and Number of Heat

As shown in Fig.4, there is an inverse correlation between fuel consumption and number of heat, and the fuel consumption per ton of ingot lowers with the increase of number of heat. This can be naturally

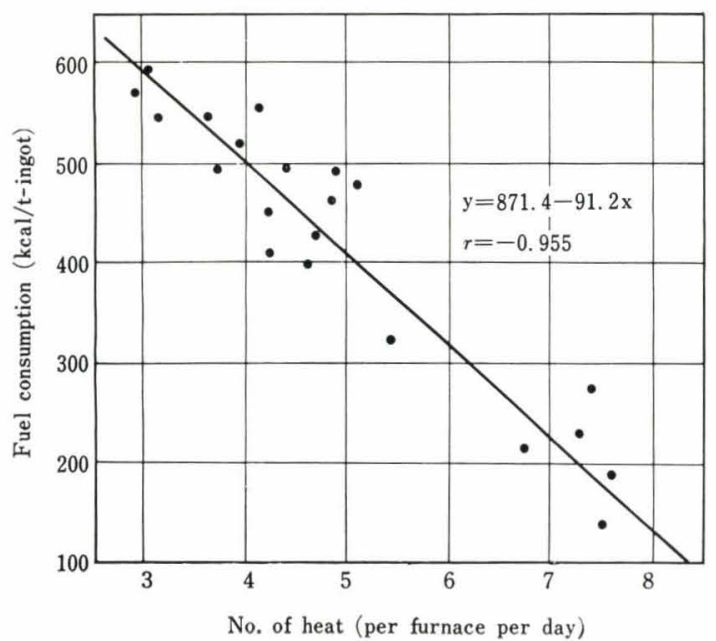

Fig. 4. Relation between number of heat and fuel consumption expected from the fact that, with an increasing amount of oxygen consumption, heat time is shortened and in addition fuel input can be regulated.

\section{Relation between Number of Heat and Roof Life}

It can be easily presumed that roof life is shortened and brick consumption per ton of ingot will rise on account of the vast splash and overheating of roof lining. The latter is caused by the increase of oxygen consumption which brings an increase in the number of heat. These circumstances can be seen in Fig.5.

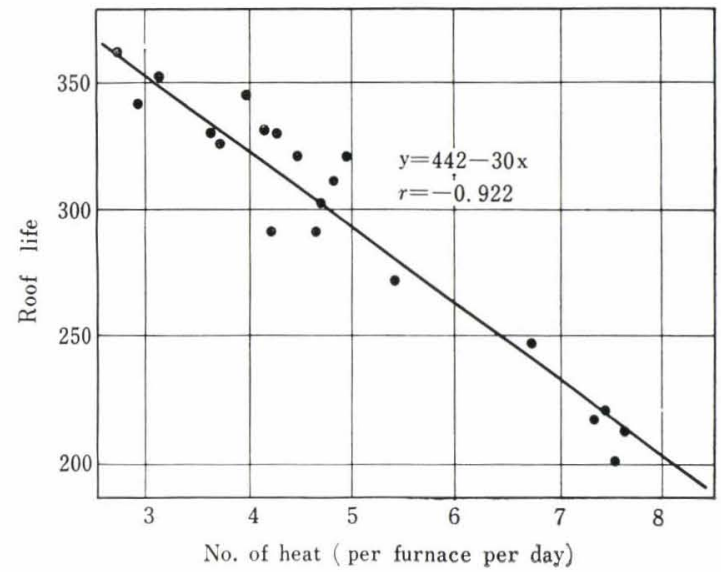

Fig. 5. Relation between number of heat and roof life

Relation between Number of Heat and Consumption of Repair Materials

In the O-H shop, dolomite clinker and dolomite stone are used for repairing the furnace bottom and front and back walls. As the amount of oxygen consumption increases, the time for sintering dolomite stone becomes insufficient because of the shortened heat time, and the consumption of dolomite clinker becomes much larger. Figs.6 and 7 show these situations.

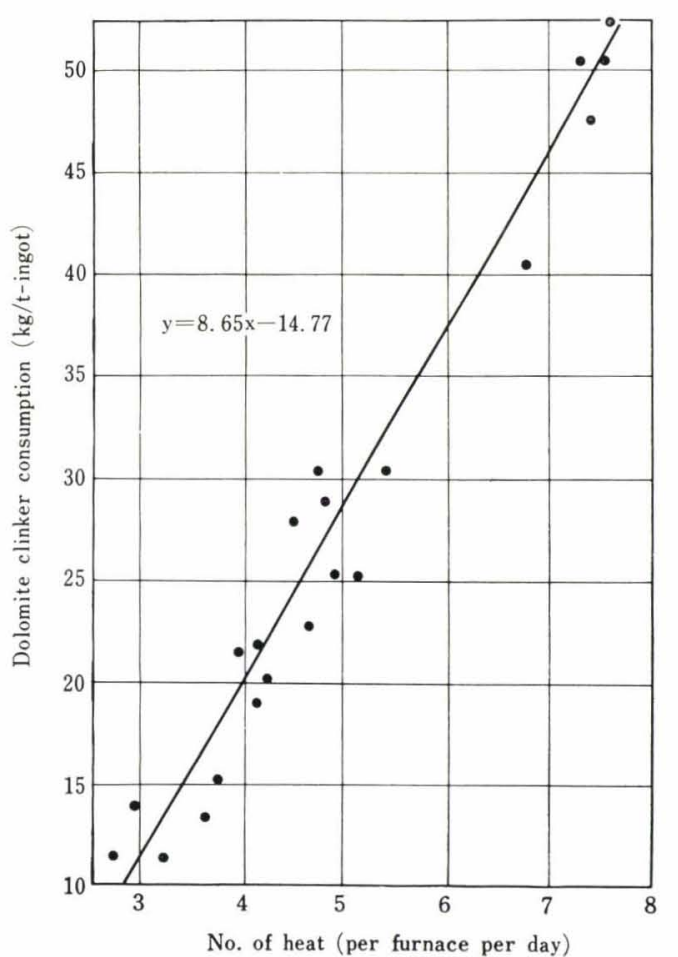

Fig. 6. Relation between number of heat and dolomite clinker consumption 


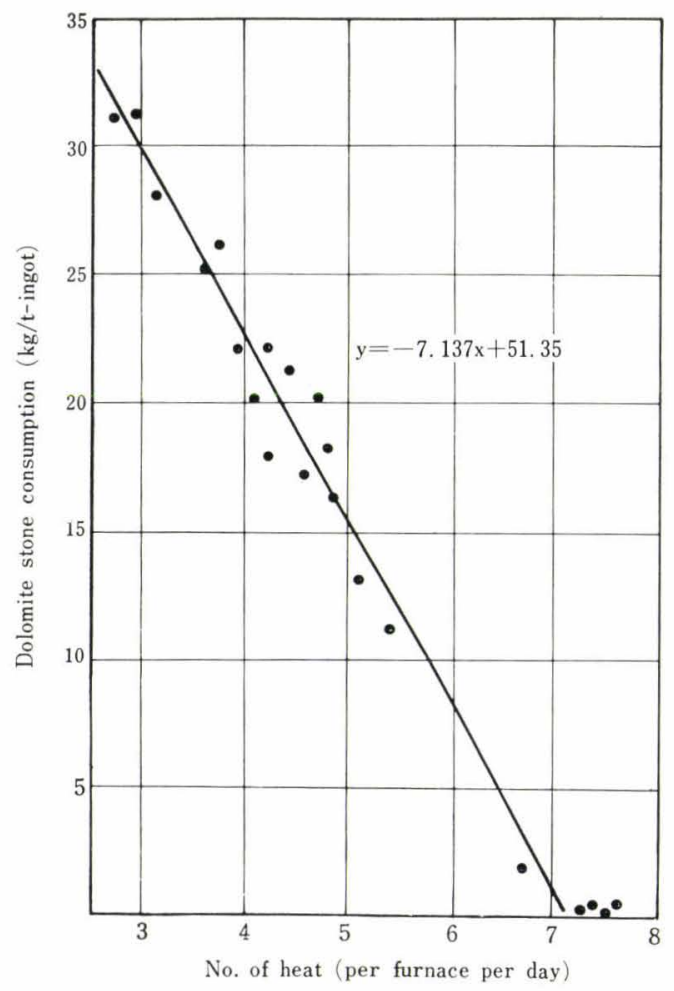

Fig. 7. Relation between number of heat and dolomite stone consumption

\section{Relation between Number of Heat and Man-Hour}

As shown in Fig. 8 man-hour per ton of ingot decreases with the increase of production, but unusual points representing man-hours for 1959 and 1962 in this figure are due to intentional increases in the labor force.

\section{Cooling Water Consumption and Volume of Waste-Heat} Steam Generated

These two factors including cooling water consump-

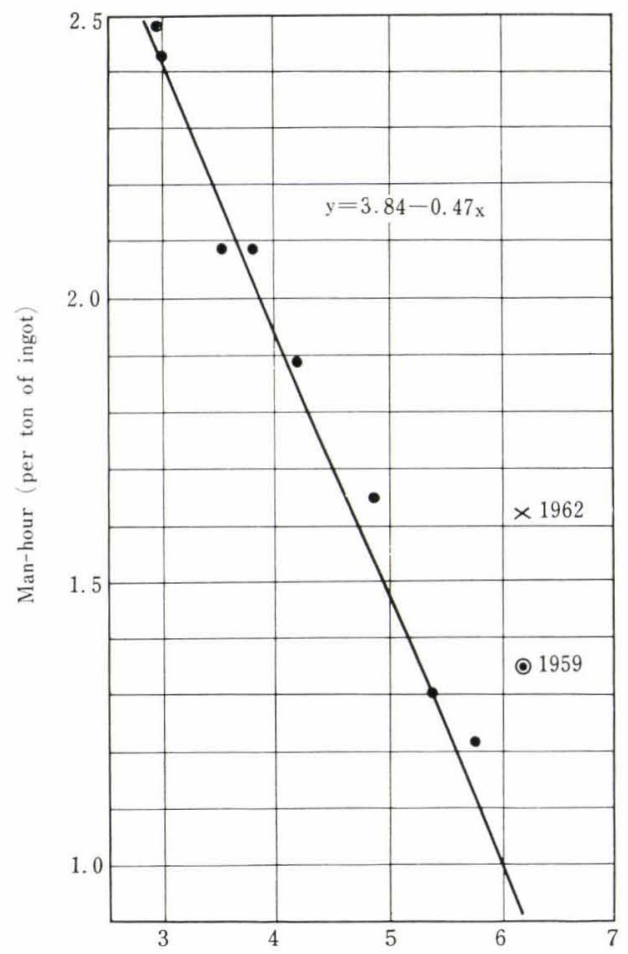

No. of heat (per furnace per day)

Fig. 8. Relation between number of heat and man-hour

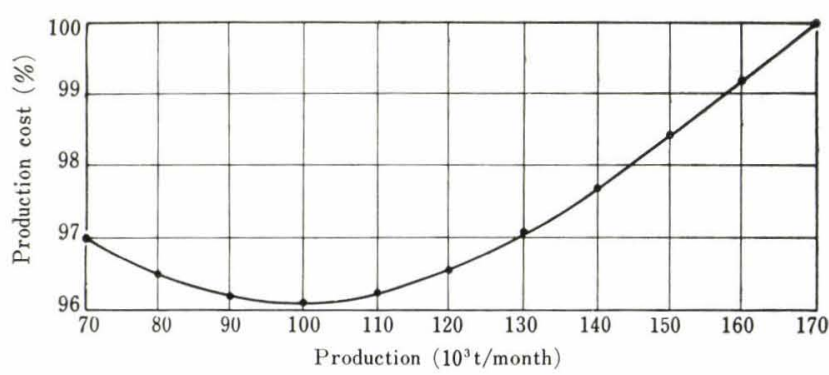

Fig. 9. Relation between output amount and production cost per ton of steel ingot

tion and volume of waste-heat steam generated per ton of ingot have a tendency to decline when production tonnage increases.

\section{Depreciation and Overhead Cost}

With an increase of production, the depreciation and overhead costs per ton of ingot are naturally reduced. Except for those described above, other factors which determine the production cost per ton of ingot remain more or less constant irrespective of the output tonnage, and may be omitted when comparing production cost for each production level. Then the relation between the production cost and amount of production is as shown in Fig.9. In this figure the production cost for 2,000,000 tons per year (roughly 170,000 tons per month) is fixed as 100 per cent, and costs for the other production levels are shown in percentages to this. From the diagram it can be seen that the production cost for about 100,000 tons per month shows the lowest value. Therefore, in order to produce ingots most economically in the O-H shop, the steelmaking capacity must be reduced to 1,200,000 tons annually even if much more ingots can actually be produced.

\section{Steelmaking Capacity of LD Shop}

The LD shop at Chiba Works has two oxygen converters, each having the inner volume of $242.4 \mathrm{~m}^{3}$ and it is producing now over 2,000,000 tons of ingots annually, and when the third converter is installed in July 1965, the production can be easily increased to max. 3,800,000 tons of ingots.

Moreover, in addition to the fact that the production cost in the LD shop is far cheaper than that of the $\mathrm{O}-\mathrm{H}$ shop, it declines in proportion to the increase in the ingot production per hour, differing from the case of the O-H shop.

Therefore, when operating both shops, it is appropriate to have the converters operated to the utmost, and so we can regard the annual capacity of the LD shop as 3,800,000 tons of ingots. Consequently, the economical production level at Chiba Works can be considered to be 5,000,000 tons of ingots per year.

On the other hand, the iron-making and rolling facilities relating to the melting shops, when the including ones now being planned, have roughly balancing capacities with 5,000,000 tons of ingot production annually as described below. Then Chiba Works will be well-balanced in capacity, as a whole, when reaching the stage of annual production of $5,000,000$ tons. 


\section{Oxygen Plant}

Oxygen generators at Chiba Works are shown in Table 2. Assuming that the total operation time per annum is 8,000 hours, the annual amount of oxygen generated will be :

$$
45,400 \mathcal{N m}^{3} / \mathrm{hr} \times 8,000=363,200,000 \mathcal{N m}^{3}
$$

Table 2. Summary of oxygen generators

\begin{tabular}{|c|c|c|c|}
\hline $\begin{array}{l}\text { Machine } \\
\text { No. }\end{array}$ & $\begin{array}{l}\text { Nominal } \\
\text { capacity } \\
\left(\mathrm{Nm}^{3} / \mathrm{hr}\right)\end{array}$ & Machine type & Date of construction \\
\hline No. 1 & 2,000 & $\begin{array}{l}\text { High and low pressure } \\
\text { regenerative, heat- } \\
\text { exchange type }\end{array}$ & Aug. 1955 \\
\hline No. 2 & 3,000 & $\begin{array}{l}\text { Low pressure regenera- } \\
\text { tive, heat-exchange type }\end{array}$ & Jun. 1958 \\
\hline No. 3 & 4,200 & , & Mar. 1960 \\
\hline No. 4 & 4,200 & , & Jun. 1961 \\
\hline No. 5 & 6,000 & , & May. 1962 \\
\hline No. 6 & 8,000 & , & Dec. 1963 \\
\hline No. 7 & 8,000 & ," & Under construction \\
\hline No. 8 & 10,000 & , & Planned \\
\hline Total & 45,400 & - & - \\
\hline
\end{tabular}

On the other hand, annual oxygen requirement is as shown in Table 3. The surplus oxygen resulting from the above calculation will be used to enrich the blast blown into the blast furnaces, or otherwise Nos.1 and 2 oxygen generators will be shut down. On the other hand, the total capacity of the oxygen plant can meet oxygen requirements of melting shops, even when large-scale generators such as Nos.6, 7 and 8 machines must be stopped for periodical repair.

Table 3. Oxygen requirement

\begin{tabular}{c|c|c}
$\begin{array}{c}\text { Production } \\
\text { tonnage } \\
(\mathrm{t})\end{array}$ & $\begin{array}{c}\text { Oxygen } \\
\text { consumption } \\
\left(N \mathrm{~m}^{3} / \mathrm{t}\right)\end{array}$ & $\begin{array}{c}\text { Annual oxygen } \\
\text { requirement } \\
\left(N \mathrm{~m}^{1}\right)\end{array}$ \\
\hline
\end{tabular}

\begin{tabular}{l|c|c|c|}
\hline O-H shop & $1,200,000$ & 40 & $48,000,000$ \\
\hline LD shop & $3,800,000$ & 50 & $190,000,000$ \\
\hline Others & - & - & $60,000,000$ \\
\hline Total & $5,000,000$ & - & $298,000,000$
\end{tabular}

\section{Demand and Supply of Scrap}

Table 4 shows annual scrap requirement for the production of 5,000,000 tons of ingots.

Since return steel scrap and iron scrap are assumed to be 750,000 and 50,000 tons, respectively, about 500,000 tons of scrap must be purchased annually. As the existing scrap yard at Chiba Works can only handle scraps of about 60,000 tons per month with an area of about $50,000 \mathrm{~m}^{2}$, new scrap unloading and stock yards are to be built at Oihama district.

Table 4. Scrap requirements

\begin{tabular}{c|c|c|c|c}
\hline $\begin{array}{c}\text { Type of } \\
\text { furnace }\end{array}$ & $\begin{array}{c}\text { Scrap } \\
\text { rate } \\
(\%)\end{array}$ & $\begin{array}{c}\text { Steelmaking } \\
\text { yield } \\
(\%)\end{array}$ & $\begin{array}{c}\text { Production } \\
\text { tonnage } \\
(\mathrm{t})\end{array}$ & $\begin{array}{c}\text { Annual scrap } \\
\text { requirements } \\
(\mathrm{t})\end{array}$ \\
\hline O-H & 25 & 92 & $1,200,000$ & 330,000 \\
\hline LD & 23 & 92 & $3,800,000$ & 950,000 \\
\hline Total & - & - & $5,000,000$ & $1,280,000$ \\
\hline
\end{tabular}

\section{Iron-Making Equipment}

\section{Hot Metal Requirements}

In the study of steelmaking capacity above-mentioned the economical production scale of annual $5,000,000$ tons of ingots takes for granted the selfsupply of pig iron. In this case iron requirement will be as shown in Table 5 .

Therefore, required daily output of hot metal will be :

$$
\frac{4,170,000 \mathrm{t}}{365}=11,400 \mathrm{t} / \mathrm{day}
$$

Table 5. Iron requirement

\begin{tabular}{|c|c|c|c|c}
\hline $\begin{array}{c}\text { Type of } \\
\text { furnace }\end{array}$ & $\begin{array}{c}\text { Production } \\
\text { tonnage } \\
(\mathrm{t})\end{array}$ & $\begin{array}{c}\text { Steelmaking } \\
\text { yield } \\
(\%)\end{array}$ & $\begin{array}{c}\text { Standard pig } \\
\text { iron rate } \\
(\%)\end{array}$ & $\begin{array}{c}\text { Pig iron } \\
\text { requirement } \\
(\mathrm{t} / \mathrm{yr})\end{array}$ \\
\hline O-H & $1,200,000$ & 92 & 75 & 980,000 \\
\hline LD & $3,800,000$ & 92 & 77 & $3,190,000$ \\
\hline Total & $5,000,000$ & - & - & $4,170,000$ \\
\hline
\end{tabular}

\section{Iron-Making Capacity}

There are five furnaces at Chiba Works, as shown in Table 6. At present four blast furnaces are in operation, and in May 1965, No.5 furnace having a working volume of $2,142 \mathrm{~m}^{3}$ is to be erected, and remarkably high productivity will be expected through the employment of the newest techniques such as high top pressure operation, fully automatic charging equipment using belt conveyer system and high temperature hot stoves of side combustion type (Koppers type). No. 2 blast furnace, after its relining scheduled in the near future, is also to adopt high top pressure operation.

\begin{tabular}{|c|c|c|c|c|}
\hline $\begin{array}{l}\text { Furnace } \\
\text { No. }\end{array}$ & $\begin{array}{c}\text { Nominal } \\
\text { capacity } \\
\text { (t/day) }\end{array}$ & $\begin{array}{l}\text { Working } \\
\text { volume } \\
\left(\mathrm{m}^{3}\right)\end{array}$ & $\begin{array}{l}\text { Date of } \\
\text { construction }\end{array}$ & Remarks \\
\hline No. 1 & 1,000 & 913 & Jun. 1953 & $\begin{array}{l}\text { Remodeled in } \\
\text { Aug. } 1963\end{array}$ \\
\hline No. 2 & 1,000 & 1,172 & Mar. 1958 & \\
\hline No. 3 & 1,500 & 1,689 & Apr. 1960 & $\begin{array}{l}\text { High top pressure } \\
\text { operation after relining }\end{array}$ \\
\hline No. 4 & 1,500 & 1,689 & Aug. 1961 & \\
\hline No. 5 & 2,000 & 2,142 & $\begin{array}{l}\text { Under con- } \\
\text { struction }\end{array}$ & $\begin{array}{l}\text { High top pressure } \\
\text { operation }\end{array}$ \\
\hline Total & 7,000 & 7,605 & & \\
\hline
\end{tabular}

Table 6. Summary of blast furnaces

Except No.2 furnace, the blast furnaces now in operation are producing hot metal at the rate of 1.40 to $1.45 \mathrm{t} / \mathrm{m}^{3} /$ day, and when the condition of metallic burdens is improved by importing high-grade iron ores and pellets, it will be easy to raise the rate to 1.50 $\mathrm{t} / \mathrm{m}^{3} /$ day in the near future with all of five furnaces operated, even at normal top pressure operation. Then tons of hot metal produced per day will amount to :

$$
1.50 \mathrm{t} / \mathrm{m}^{3} / \text { day } \times 7,605 \mathrm{~m}^{3}=11,400 \mathrm{t} / \mathrm{day},
$$

and hot metal requirement for steelmaking can be 
fulfilled.

On the other hand, as a blast furnace must usually be relined every six years, it is necessary to reline approximately one furnace in a year when five furnaces are in operation. Therefore, it is reasonable to preserve enough capacity of production by adopting high top pressure operation and by oxygen enrichment of blast, in order to cope with the shortage of hot metal and to self-supply the necessary amount of hot metal in the case of relining any blast furnace. Furthermore even when such a large furnace as No. 5 must be relined, it will be possible to cover shortage of pig iron by storing cold metal previously.

\section{Iron Ores}

As for iron ores, it is necessary to study materialhandling capacity in the plant, grades of imported iron ores and the rate of sinter and pellet to the total ore.

Due to the limited area of ore-storage yards, necessarily high grade ores must be selected and their origins must be limited, and plans must be made to import oversea pellets and increase the amount of sized ores, as the ores presently supplied are apt to bring excess fines. When high grade of sized ores and pellets can be imported, the ore rate will decrease to 1.50 to 1.55 (average 1.53) tons per ton of pig iron, and also coke rate to about 450 to $470 \mathrm{~kg} / \mathrm{t}$ pig, considering heavy oil injection of 40 to $50 \mathrm{~kg} / \mathrm{t}$ pig. With the ore rate of $1.53 \mathrm{t} / \mathrm{t}$-pig, iron ore requirement will amount to $6,400,000$ tons for annual hot metal production of 4,170,000 tons. Assuming that the ratio of sinter and pellet to all metallic burdens is $70 \%$, the sinter and pellet requirement is roughly $4,500,000$ tons. Since the annual production of sinter and pellet in the plant is about 3,200,000 tons, as shown in Table 7, 1,300,000 tons of pellets have to be purchased from abroad.

Table 7. Pellet and sinter plants

\begin{tabular}{|c|c|c|c|}
\hline & Plant & $\begin{array}{c}\text { Capacity } \\
\text { (t/day) }\end{array}$ & Remarks \\
\hline \multirow{3}{*}{ Pellet } & No. 1 pellet plant & 900 & Kawasakiseitetsu type \\
\hline & No. 2 & ," & , \\
\hline & No. 3 & 2,000 & , \\
\hline \multirow{2}{*}{ Sinter } & No. 1 sinter plant & 2,400 & Dwight Lloyd type \\
\hline & No. 2 & , & ," (Under construction) \\
\hline Total & & \multicolumn{2}{|c|}{$8,600 \mathrm{t} /$ day $=3,200,000 \mathrm{t} /$ year } \\
\hline
\end{tabular}

\section{Ore-Storage Yards and Transportation of Ores}

As shown in Table 8, the ore yard consists of orestorage yard having an area of $81,000 \mathrm{~m}^{2}$ and ore bedding yard of $48,000 \mathrm{~m}^{2}$ and the former is supposed to be able to store 788,000 tons and the latter, 150,000 tons of ores. Plans are now under way to prepare another ore-storage yard of $20,000 \mathrm{~m}^{2}$ to store over 180,000 tons of ores. Thus the total storage capacity for iron ores will become 1,120,000 tons, or equivalent to two months' requirement of total 6,400,000 tons in a year.
Table 8. Ore-storage yards and ore-bedding yards

\begin{tabular}{c|c|c}
\hline Yard & $\begin{array}{c}\text { Area } \\
\left(\mathrm{m}^{2}\right)\end{array}$ & $\begin{array}{c}\text { Maximum storage } \\
\text { volume }\end{array}(\mathrm{t})$ \\
\hline Lump ore storage yard & 43,240 & 465,000 \\
\hline Fine ore storage yard & 37,740 & 323,000 \\
\hline Ore-bedding yards & 48,000 & 150,000 \\
\hline
\end{tabular}

The ore-conveying system has been found to have sufficient capacity to transport ores, until the production of hot metal amounts to $12,000 \mathrm{t}$ /day.

\section{Demand and Supply of Coke and Coal-Storage Yard}

As seen in Table 9, five coke ovens can produce a total of 5,480 tons of cokes per day. With the coke rate of $470 \mathrm{~kg} / \mathrm{t}$-pig, coke requirement for daily hot metal production of 11,400 tons will be 5,360 t/day, which will be supplied sufficiently from these coke ovens.

Table 9. Outlook of coke ovens

\begin{tabular}{|c|c|c|c|c|}
\hline Coke oven No. & $\begin{array}{l}\text { No, of } \\
\text { chambers }\end{array}$ & $\begin{array}{l}\text { Nominal } \\
\text { capacity } \\
\text { (t/day) }\end{array}$ & Type & $\begin{array}{l}\text { Date of } \\
\text { construction }\end{array}$ \\
\hline No. 1 coke oven & 54 & 700 & $\begin{array}{l}\text { New Otto double } \\
\text { block system }\end{array}$ & Jun. 1953 \\
\hline No. 2 & 60 & 780 & ," & Mar. 1959 \\
\hline No. 3 & 74 & 1,000 & $\begin{array}{c}\text { (remodeled) } \\
\text { (rem }\end{array}$ & Nov. 1960 \\
\hline No. 4 & 74 & 1,000 & $\begin{array}{c}\text { (remodeled) } \\
\text { (rem }\end{array}$ & Mar. 1962 \\
\hline No. 5 & 92 & 2,000 & Carl-Still & $\begin{array}{l}\text { Under con- } \\
\text { struction }\end{array}$ \\
\hline Total & - & 5,480 & & \\
\hline
\end{tabular}

On the other hand, as annual coke requirement is :

$$
5,360 \mathrm{t} / \text { day } \times 365=1,950,000 \text { tons }
$$

and annual coal requirement in dry state amounts to :

$$
\frac{1,950,000 \text { tons }}{0.67}=2,900,000 \text { tons }
$$

A coal-storage yard, having an area of $115,000 \mathrm{~m}^{2}$, is able to store 370,000 tons of coal, which corresponds to about one and half months' requirement, and this will create no difficulty in operation because the sources of supply are limited.

\section{Unloading at the Wharf}

The front wharf for unloading coal and iron ore consists of Nos.1 and 2 front wharfs and the coal wharf. Table 10 shows the details. As mentioned above, at the time when 5,000,000 tons of ingots are produced annually, 6,400,000 tons of iron ores and 2,900,000 tons of coal are required, and unloading of these raw materials is found to be possible, as is explained in the following :

\section{Iron Ore}

Capacity of unloaders

at No.1 front wharf (4 sets) : 140,000 t/month

at No.2 , (, ): 600,000 , 
Table 10. Summary of unloaders

\begin{tabular}{|c|c|c|c|c|c|c|}
\hline \multirow[b]{2}{*}{ Raw material } & \multirow[b]{2}{*}{ Name of wharf } & \multirow{2}{*}{$\begin{array}{l}\text { Length of wharf } \\
(\mathrm{m})\end{array}$} & \multirow{2}{*}{$\begin{array}{l}\text { Depth of water } \\
\text { (m) }\end{array}$} & \multicolumn{2}{|c|}{ Unloaders } & \multirow[b]{2}{*}{ Remarks } \\
\hline & & & & $\underset{(\mathrm{t} / \mathrm{hr})}{\text { Capacity }}$ & No. of units & \\
\hline \multirow{2}{*}{ Iron ore } & No. 1 front & 500 & 9.5 & $\begin{array}{l}175 \\
150\end{array}$ & $\begin{array}{l}3 \\
1\end{array}$ & Common berth for ore and coal \\
\hline & No. 2 front & 560 & 12 & $\begin{array}{l}500 \\
480\end{array}$ & $\begin{array}{l}3 \\
1\end{array}$ & Exclusive use for ore \\
\hline \multirow{2}{*}{ Coal } & No. 1 front & 500 & 9.5 & 150 & 3 & Common berth \\
\hline & Coal & 270 & 12 & 500 & 2 & Exclusive use for coal \\
\hline
\end{tabular}

Amount of ores to be unloaded :

$$
\frac{6,400,000}{12}=533,000 \mathrm{t} / \mathrm{month}
$$

Amount of ores to be unloaded at the peak time (peak rate $=1.3): 533,000 \mathrm{t} \times 1.3=700,000 \mathrm{t} / \mathrm{month}$

Consequently, the existing unloaders can handle the required amount of ores.

\section{Coal}

Unloading capacity

at No.1 front wharf ( 3 sets $): 145,000 \mathrm{t} / \mathrm{month}$

at the coal wharf,

from coal carriers : $310,000 \mathrm{t} /$ month

from common carriers : 245,000 t/month

Amount of coal to be unloaded: $2,900,000 \mathrm{t} / 12=242,000 \mathrm{t} / \mathrm{month}$

Amount of coal to be unloaded at the peak time (peak rate $=1.3$ ) $: 315,000 \mathrm{t} /$ month.

Assuming that the rate of coal to be unloaded from coal carriers to the total amount is 30 per cent, the amount to be unloaded will be :

from coal carriers : $315,000 \mathrm{t} \times 0.3=94,500 \mathrm{t} / \mathrm{month}$ from common carriers :

$$
315,000 \mathrm{t} \times 0.7=220,500 \mathrm{t} / \mathrm{month}
$$

These amounts can be unloaded by the existing unloaders.

\section{Rolling Facilities}

Table 11 shows outline of rolling facilities at Chiba Works.

\section{Slabbing Mill}

No. 1 Slabbing and Blooming Mill

This is a reversing mill of high lift type which came into operation in September 1954, and its annual rolling capacity was $1,200,000$ tons at the start, but with such subsequent improvements as tandem rolling, it can now roll annually 1,800,000 tons of ingots. This plant has AMCO type, bottom fired soaking pits which have been operating satisfactorily since their installment.

\section{No. 2 Slabbing Mill}

This is a universal-type mill, which started operation in October 1961 for producing slabs especially for wide plates and wide strips, and its annual rolling capacity is 4,000,000 ton ingots.

Soaking pits in this plant are equipped with apparatus to predict the time required for taking out ingots by the electronic computer, and their operation has been properly carried out.

\section{Hot Rolling Mill}

\section{No. 1 Hot Strip Mill}

This is a 56 -in wide semi-continuous hot strip mill, which rolls 1,620,000 tons a year, and produces hot coils of relatively thin gauge by rolling slabs from No.1 slabbing and blooming mill.

\section{No. 2 Hot Strip Mill}

This plant contains a 80-in wide fully continuous hot strip mill, which is now on the highest level of this type and was put into operation in October 1963, and is designed to roll annually 3,000,000 tons of slabs. The finishing train consists of five stands, and when seven stands are installed, eventually the maximum coiling speed is $1,000 \mathrm{~m} / \mathrm{min}$. This is equipped with A.G.C. system with hydraulically and pneumatically driven loopers for producing coils of little tolerance

\begin{tabular}{|c|c|c|c|c|c|}
\hline Name of mill & Type & $\underset{(\mathrm{t} / \mathrm{yr})}{\text { Rolling capacity }}$ & Date of construction & \multicolumn{2}{|l|}{ Remarks } \\
\hline $\begin{array}{l}\text { No. } 1 \text { slabbing } \& \text { blooming mill } \\
\text { No. } 2 \text { slabbing mill }\end{array}$ & $\begin{array}{l}\text { High lift } \\
\text { Universal }\end{array}$ & $\begin{array}{l}1,800,000 \text { (ingot) } \\
4,000,000 \text { (ingot) }\end{array}$ & $\begin{array}{l}\text { Sept. } 1954 \\
\text { Oct. } 1961\end{array}$ & & \\
\hline Total & & $5,800,000$ (ingot) & & & \\
\hline $\begin{array}{l}\text { No. } 1 \text { hot strip mill } \\
\text { No. } 2 \text { hot strip mill } \\
\text { Plate mill }\end{array}$ & $\begin{array}{l}\text { Semi-continuous } \\
\text { Fully continuous }\end{array}$ & $\begin{array}{r}1,620,000 \text { (slab) } \\
3,000,000 \text { (slab) } \\
720,000 \text { (slab) }\end{array}$ & $\begin{array}{l}\text { Apr. } 1958 \\
\text { Oct. } 1963 \\
\text { Apr. } 1961\end{array}$ & Barrel length & $\begin{array}{l}56 \text { in } \\
80 \text { in }\end{array}$ \\
\hline Total & & $5,340,000(\mathrm{slab})$ & & & \\
\hline $\begin{array}{l}\text { No. } 1 \text { cold strip mill } \\
\text { No. } 2 \\
\text { No. } 3 \\
\text { No. } 4\end{array}$ & $\begin{array}{l}\text { 5-tandem } \\
\text { 6-tandem } \\
\text { Reversing } \\
\text { 5-tandem }\end{array}$ & $\begin{array}{l}480,000 \text { (hot coil) } \\
600,000 \text { (hot coil) } \\
240,000 \text { (hot coil) } \\
780,000 \text { (hot coil) }\end{array}$ & $\begin{array}{l}\text { Jun. } 1958 \\
\quad \text { Apr. } 1963 \\
\text { Under construction } \\
\text { Planned }\end{array}$ & Barrel length & $\begin{array}{l}56 \text { in } \\
56 \text { in } \\
80 \text { in } \\
68 \text { in }\end{array}$ \\
\hline Total & & $2,100,000$ (hot coil) & & & \\
\hline
\end{tabular}

Table 11. Outline of rolling facilities 
in thickness. The computer control system in this mill is now being developed in co-operation with an electric company.

\section{Plate Mill}

This mill which started operating in April 1961 can roll 720,000 tons of slabs a year, and can produce plates up to $3.9 \mathrm{~m}$ wide by the rolls of $4.2 \mathrm{~m}$ long. As the diameter of back-up roll is $1.7 \mathrm{~m}$, plates of little tolerance in thickness can be produced. This plant is equipped with heat treating equipment for producing various kinds of high-tension steel plates.

\section{Cold Rolling Mill}

\section{Cold Strip Mills}

The total output of cold strip mills including those now in the planning stage is 2,100,000 t/yr. Among them, the 56-in wide 6-tandem mill newly erected in April 1963, can produce cold strips of min. $0.1 \mathrm{~mm}$ thick with its max. rolling speed of $2,130 \mathrm{~m} / \mathrm{min}$.

\section{Secondary Processing Equipment}

A continuous galvanizing line capable of producing $80,000 \mathrm{t} / \mathrm{yr}$. is now in operation and another line is being planned. The type of these lines is remodeled from one of those now commonly used throughout the world and can be called Kawasakiseitetsu.

The installation of a continuous tinning line is under consideration, the annual production capacity of which will be 100,000 tons.

The flow diagram of materials at the production level of 5,000,000 tons of ingots from the unloading of the iron ore and coal to rolling is shown in Fig. 10. As seen from the diagram, the rate of operation of each rollig mill is from 80 to 90 per cent. Considering the lowering in capacity due to the rolling various kinds and sizes of products, the rolling capacity of the plant is regarded as adequate.

\section{Transportation}

The transport route of hot metal and semi-finished products among plants at the time of annual output of 5,000,000 tons of ingots is shown in Fig.11. The flow from the blast furnace is divided into two main routes : the one is from the O-H shop, via No.1 slabbing and blooming, No.1 hot strip and Nos.1 and 2 cold strip mills to the north wharf and the other is from the LD shop via No.2 slabbing, No.2 hot strip and plate mills to the south wharf. As seen from the diagram, transportation at any point can be conducted very smoothly.

\section{Hot Metal}

Hot metal is transported from each blast furnace to $\mathrm{O}-\mathrm{H}$ and $\mathrm{LD}$ shops daily in the amount of 11,400 tons on the average, with a maximum of 12,500 tons.

Table 12. Transport of hot metal

\begin{tabular}{l|c|c|c|c}
\hline \multirow{2}{*}{} & \multicolumn{2}{|c|}{ Amounts to be transported } & \multicolumn{2}{|c}{ No. of ladles to be required } \\
\cline { 2 - 5 } & $\begin{array}{c}\text { Average } \\
\text { (t/day) }\end{array}$ & $\begin{array}{c}\text { Max. } \\
\text { (t/day) }\end{array}$ & Average & Max. \\
\hline To O-H & 2,700 & 3,000 & 45 & 50 \\
\hline To LD & 8,700 & 9,500 & 145 & 158 \\
\hline Total & 11,400 & 12,500 & 190 & 208 \\
\hline
\end{tabular}

Table 12 shows the tranport of hot metal, where the ladle contains 60 tons of hot metal on an average. Judging from the actual results so far obtained, the number of hot metal-carrying trains will be 42 to 47 per day, each train consisting of 4.5 cars and with favorable condition, it is possible to match the train schedule with the tapping time of each blast furnace.

\section{Ingots}

As a rule, all ingots from the open hearth furnaces are transported to No.l slabbing and blooming mill, and most of those from the LD converters are hauled to No. 2 slabbing, with the balance going to No. 1 slabbing mill. Since distance between the melting shop and the rolling mill is short in either case, a smooth transport of ingots can be expected.

\section{Slabs}

Usually, slabs from No.1 slabbing and blooming mill are transported to the neighboring No.1 hot strip mill, and those from No.2 slabbing are hauled to the adjacent No.2 hot strip mill with ease. Even in rare cases where it is necessary to transport slabs from No.1 slabbing to No.2 hot strip and plate mill or from No.2 slabbing to No.l hot strip mill, there will be no great difficulty.

\section{Hot Coil}

Hot coils from No.1 hot strip mill are transfered through pickling lines to Nos. 1 and 2 cold strip mill shops, without any obstacle. The major part of hot coils produced by No. 2 hot strip mill will be transferred, with ease, to Nos. 3 and 4 strip mills to be installed at Oihama compound.

\section{Shipping of Products}

All products are shipped from three shipping yards, two of which are situated at the north and south ends of Chiba compound and the other is located at Oihama compound, as shown in Fig. 11.

\section{Energy Balance}

\section{Electric Power}

Annual requirement of electric power for the output of 5,000,000 tons of ingots is 1,600 million $\mathrm{kWH}$ as seen in Fig. 12 which shows power balance. Of this amount 500 million $\mathrm{kWH}$ is supplied by the home power plant and 1,100 million $\mathrm{kWH}$ is to be purchased, as shown in Table 13.

The total generating capacity of the power plant in the plant is $80,000 \mathrm{~kW}$ per hour, and when the power plant's availability is about 75 per cent, the actual generated power will be $58,000 \mathrm{~kW}$ in average and even in the maximum.

Table 13. Demand and supply of electric power

\begin{tabular}{l|c|c|c} 
& $\begin{array}{c}\text { Power required } \\
(\mathrm{kW} / \mathrm{hr})\end{array}$ & $\begin{array}{c}\text { Home generated } \\
\text { power } \\
(\mathrm{kW} / \mathrm{hr})\end{array}$ & $\begin{array}{c}\text { Power purchased } \\
(\mathrm{kW} / \mathrm{hr})\end{array}$ \\
\hline Average & 183,000 & 58,000 & 125,000 \\
\hline Maximum & 232,000 & 58,000 & 174,000 \\
\hline
\end{tabular}

2. Steam

The steam balance is shown in Fig. 13. The total 


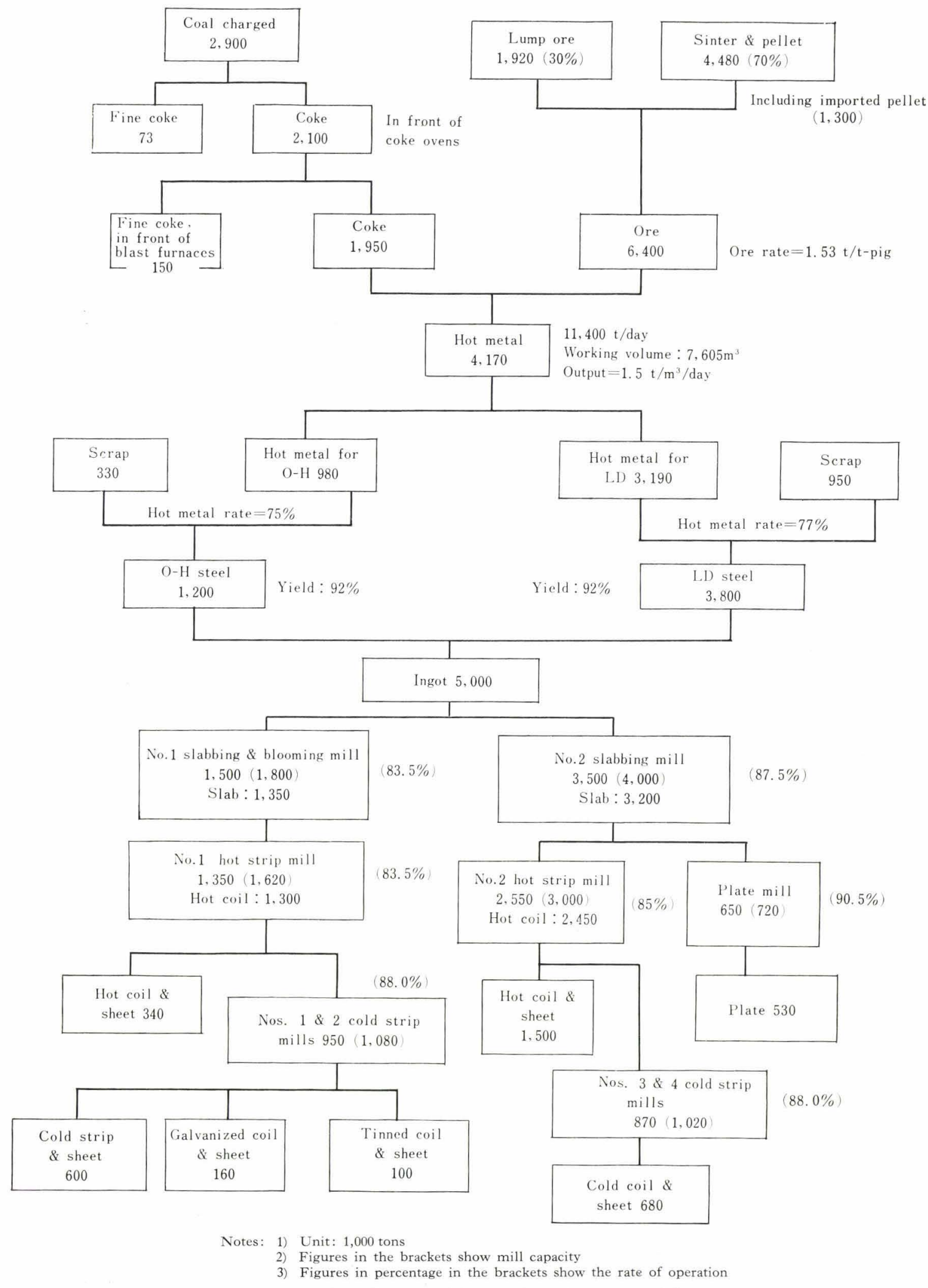

Fig. 10. Flow diagram of iron and steel raw materials

output of steam is supposed to be about 2,200,000 tons a year, of which 1,900,000 tons are used in each plant, the balance being in the power plant. It should be noticed that at Chiba Works over 75 per cent of the steam output is generated from waste heat boilers.

\section{Heat Quantities}

The total quantity of heat in the plant is $14 \times 10^{14}$ kcal as shown in Fig. 14. Blast furnace gas is reserved in the $150,000 \mathrm{~m}^{3}$ gas holder, coke oven gas in the 30,000 and $40,000 \mathrm{~m}^{3}$ gas holders. Gases are supplied to each plant solely or as mixed gas.

In Chiba Works there is used heavy oil of high sulphur content for general use, low sulphur for the blast furnace and very low sulphur oil for the open hearth furnace, which are pumped from the front wharf to 


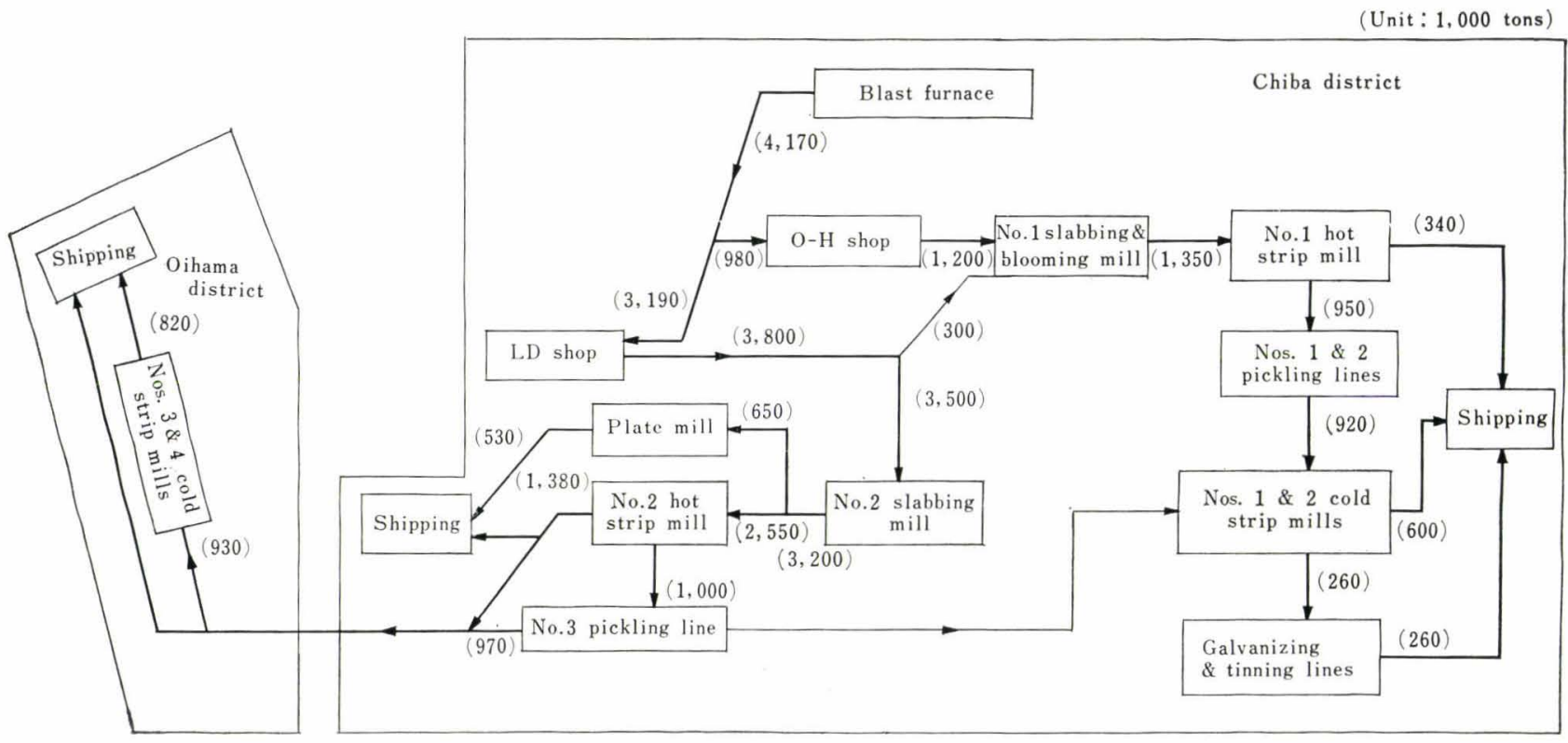

Fig. 11. Transport routes of hot metal and semi-finished products

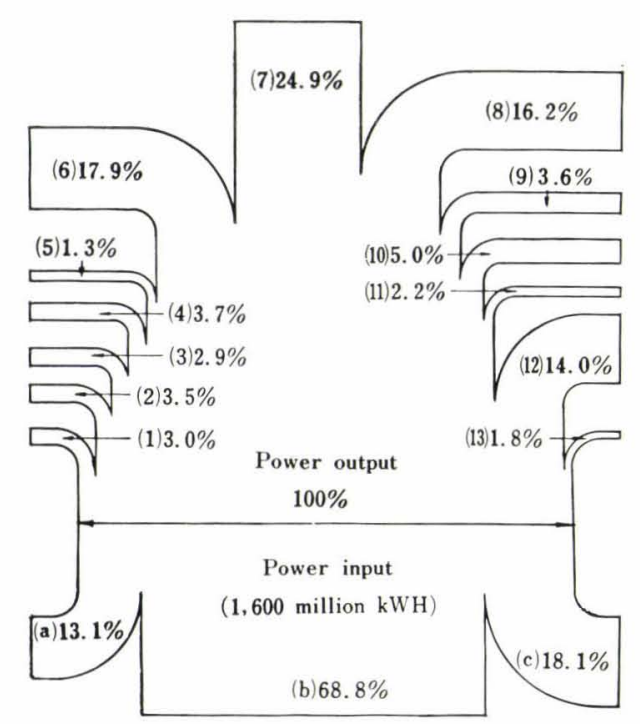

Power input

(a) No. 1 power plant

(b) Purchased power

(c) No. 2 power plant
Power output
(1) Blast furnace
(2) Pellet plant
(3) Sinter plant
(4) Coke oven
(5) $\mathrm{O}-\mathrm{H}$
(6) Hot rolling
(7) Oxygen plant
(8) Cold rolling
(9) Plate mill
(10) Slabbing mill
(11) LD converter
(12) Loss
(13) Others

Fig. 12. Electric power balance

6000-t, 2500-t, 5000-t and 1500-t oil storage tanks, respectively.

\section{Cooling Water}

\section{Seawater}

Seawater is taken in through two pipelines from the front wharf to Nos. 1 and 2 seawater pump station, which in turn supplies to each plant using seawater. The breakdown of seawater consumption at the

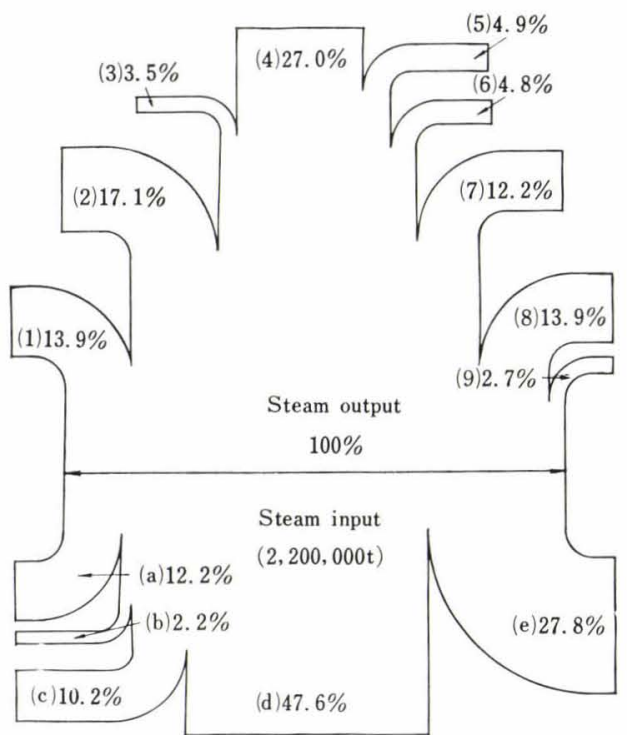

Steam input

(a) Front $\&$ back wall hot cooling boiler, $\mathrm{O}-\mathrm{H}$ shop

(b) Reheating furnace boiler

(c) O-H shop waste heat boiler

(d) LD shop waste heat boiler

(e) Central boiler

Steam output

(1) Iron-making

(2) Coking

(3) Steelmaking

(4) Rolling

(5) Secondary products

(6) Pipe loss

(7) Fan-driving

(8) Power generating

(9) Others

Fig. 13. Steam balance

time of annual output of 5,000,000 tons of ingots is shown in Fig. 15, and daily consumption will amount to about $1,200,000 \mathrm{~m}^{3}$, which is equivalent to about $88 \mathrm{~m}^{3}$ per ton of ingot.

\section{Fresh Water}

In the early period of the operation of Chiba Works, fresh water was supplied from deep wells drilled in the site, but as a shortage was estimated with the increase of steel output, the equipment for drawing fresh water of max. $77,500 \mathrm{~m}^{3} /$ day from Imba Lake was completed in April 1963. 


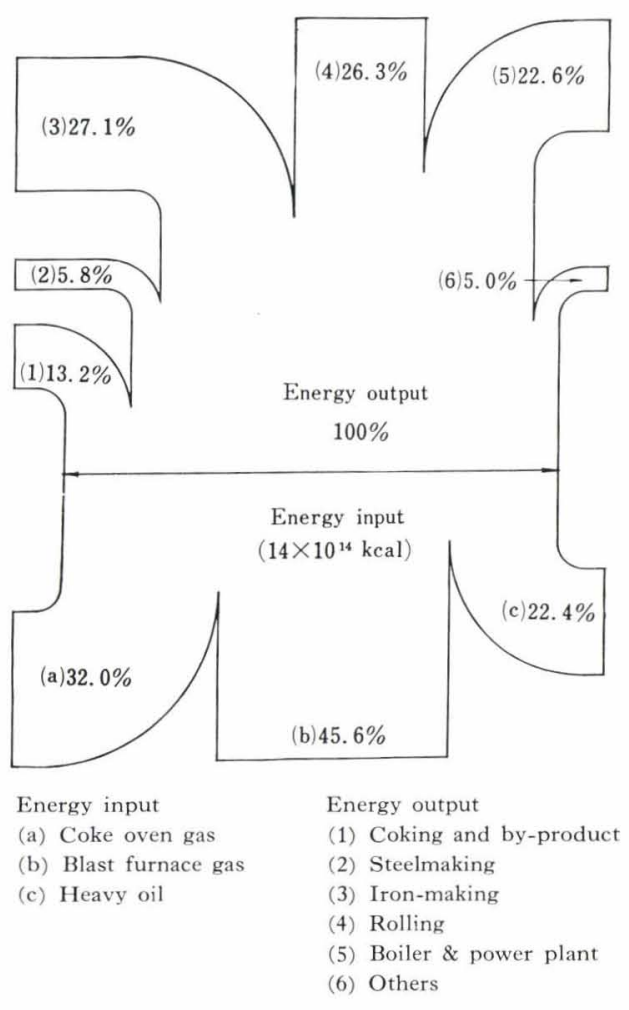

Fig. 14. Heat balance

The daily use of fresh water for the annual output of $5,000,000$ tons of ingots will be approximately $650,000 \mathrm{~m}^{3}$, or equal to $48 \mathrm{~m}^{3}$ per ton of ingot, 80 per cent of which is recirculated. Fresh water consumption comes to about $7 \mathrm{~m}^{3}$ per ton of ingot, which corresponds to $98,000 \mathrm{~m}^{3}$ per day. Of this amount, $63,000 \mathrm{~m}^{3}$ is supplied from Imba Lake.

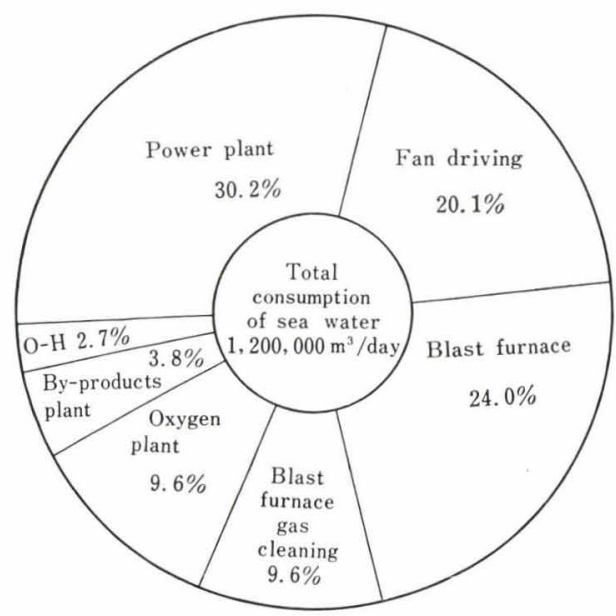

Fig. 15. Consumption of sea water

\section{Conclusions}

The annual steel output at Chiba Works has been raised from the initial $1,000,000$ tons of ingots to the present 4,000,000 tons. But judging from the economy at the stage of steelmaking it is found reasonable to set annual production at 5,000,000 tons, other equipment being nearly balanced with the steelmaking capacity, even though these have some surplus capacities. At the completion of Chiba Works, annual production will amount to $5,000,000$ tons of ingots to total about $4,000,000 \mathrm{~m}^{2}$ land and about 14,000 employees. Thus, the productivity of the Works will be 1.25 tons per $\mathrm{m}^{2}$ of land and 360 tons per man, and these represent satisfactory productivity as an integrated plant.

After the completion of Chiba Works in this scale, the Company will launch into the construction of Mizushima Works which will be the newest and largest plant in Japan. 